\title{
Clinical Outcome of Nonfistulous Cerebral Varices: the Analysis of 39 Lesions
}

\author{
Hye Seon Kim, M.D., ${ }^{1}$ Seong-Cheol Park, M.D., Ph.D., ${ }^{2}$ Eun Jin Ha, M.D., Wong-Sang Cho, M.D., Ph.D., \\ Seung-Ki Kim, M.D., Ph.D., Jeong Eun Kim, M.D., Ph.D.' \\ Department of Neurosurgery,' Seoul National University Hospital, Seoul, Korea \\ Department of Neurosurgery, ${ }^{2}$ GangNeung Asan Hospital, Gangneung, Korea
}

Objective : Cerebral varices (CVs) without an arteriovenous shunt, so called nonfistulous CVs, are very rare, and their etiology and natural course are not well understood. The aim of this study is to evaluate the clinical outcomes of nonfistulous CVs by the analysis of 39 cases.

Methods : From 2000 to 2015, 22 patients with 39 nonfistulous CVs ( $\geq 5 \mathrm{~mm}$ ) were found by searching the medical and radiologic records of our institute. Clinical data and radiological data including numbers, sizes and locations of CVs and associated anomalies were retrospectively collected and analyzed. Previously reported cases in literature were reviewed as well.

Results : The mean age of the patients was 21 years (range, $0-78$ years). On average, $1.8 \pm 1.2$ CVs were found per patient. CVs were categorized as either fusiform or saccular depending on their shapes. Two patients had saccular type CVs, seventeen patients had fusiform types, and three patients had both fusiform and saccular CVs. Eight patients had associated compromise of the vein of Galen and the straight sinus. Four of those patients had sinus pericranii, as well. Five patients had CVs that were distal draining veins of large developmental venous anomalies. One patient had associated migration anomaly, and two patients had SturgeWeber syndrome. Six patients with an isolated cerebral varix were observed. Of the $39 \mathrm{CVs}$ in 22 patients, 20 lesions in 14 patients were followed up in outpatient clinics with imaging studies. The average follow-up duration was 6.6 years. During this period, no neurological events occurred, and all the lesions were managed conservatively.

Conclusion : Nonfistulous CVs seemed to be asymptomatic in most cases and remained clinically silent. Hence, we suggest conservative management.

Key Words : Central nervous system venous angioma · Central nervous system vascular malformations.

\section{INTRODUCTION}

A cerebral varix (CV), also known as a cerebral venous aneurysm, is dilatation of a single vein or, infrequently, dilatation of several focal veins ${ }^{15}$. It is a rare vascular malformation and is often associated with an arteriovenous shunt, such as arteriovenous malformation ${ }^{22}$. However, a few cases without arteriovenous shunts have been reported.

CVs found with an arteriovenous shunt, so called fistulous CVs, are thought to be formed by high arterial pressure on ve-

- Received : April 19, 2018 • Revised : May 18, 2018 •Accepted : May 31, 2018

- Address for reprints : Eun Jin Ha, M.D.

Department of Neurosurgery, Seoul National University Hospital, 101 Daehak-ro, Jongno-gu, Seoul 03080, Korea

Tel : +82-2-2072-2824, Fax : +82-2-744-8459, E-mail : hejce1001@hanmail.net

This is an Open Access article distributed under the terms of the Creative Commons Attribution Non-Commercial License (http://creativecommons.org/licenses/by-nc/4.0) which permits unrestricted non-commercial use, distribution, and reproduction in any medium, provided the original work is properly cited. 
nous drainage system ${ }^{36)}$. There is a well-known association between fistulous CVs and hemorrhage ${ }^{22}$. Therefore, it is generally accepted that patients with fistulous CVs should be carefully followed up and treated if possible. In contrast, nonfistulous CVs, which are unrelated to arteriovenous shunts, are much less common; the biological characteristics of these lesions are only speculation, and their tendency to rupture or thrombose is unknown. Therefore, guidance on CV management has not yet been clearly expressed.

The aim of this study is to report our experience with the clinical outcomes of nonfistulous CVs, as well as review the pertinent literature.

\section{MATERIALS AND METHODS}

This retrospective study was approved by the Institutional Review Board (1609-005-787). Brain magnetic resonance (MR) and transfemoral cerebral angiography (TFCA) reports from January 2001 through December 2015 were examined for the terms "venous varix", "venous dilatation", "dilated vein", "enlarged vein", "venous enlargement", "dilatation of vein", and "venous angioma". After the search, the exclusion criteria were applied to filter the irrelevant cases. The exclusion criteria were as follows : 1) CVs with arteriovenous shunts, 2) CVs with a size less than $5 \mathrm{~mm}$ in diameter, or 3) sinus pericranii (SP) without any intracranial component. Medical records and imaging data were retrospectively reviewed, and 22 patients with $39 \mathrm{CVs}$ were included for the study.

All 22 patients were evaluated with MR imaging. Sixteen patients were also examined by TFCA, and magnetic resonance venographies were performed in six patients. The sizes of the CVs were measured on enhanced T1 MR images by the PACS software (Infinitt PACS 5.0; Infinitt Healthcare, Seoul, Korea). When there was no T1-enhanced sequence, the size was measured in the $\mathrm{T} 2$ sequence. The most recent scans were used for the CV measurement.

Clinical information was derived from the identified patients in three categories and 10 aspects : 1) demographic data (age, sex, and presenting symptoms); 2) radiographic data (number, size, location, associated vascular or other anomalies, relationships between the lesion and anomalies); and 3) treatment methods and clinical outcomes.
The diameter of CVs were measured in a direction perpendicular to the flow of CV. Diameters were measured in available orientations including transverse, sagittal and coronal planes. The longest diameter was selected as the diameter of the CV. When the length of the dilatation was less than two times of the diameter of the $\mathrm{CV}$, the $\mathrm{CV}$ was referred to be saccular. When the length of the dilatation is longer than two times of the maximum diameter, the $\mathrm{CV}$ was recognized as a fusiform type.

The threshold diameter was determined to be $5 \mathrm{~mm}$ based on two facts. First, the smallest size of cerebral varices in the literature was $5 \mathrm{~mm}^{32,33)}$. Second, the diameter of the Sylvian vein, one of the largest veins excluding the venous sinuses and the vein of Galen, ranged from 1.7 to $3.2 \mathrm{~mm}$ in an investigation of 260 patients ${ }^{1)}$. Thus, we thought that the $5 \mathrm{~mm}$ threshold was enough to include the majority of cerebral varices and exclude normal veins.

\section{Literature review of pertinent clinical studies}

The MEDLINE database was searched from 1970 to 2017 using the search terms "cerebral varix", "cerebral venous angioma", "cerebral venous aneurysm", "non-fistulous CVs", and "isolated CVs", and reports dealing with fistulous CVs were excluded. Clinical and radiological data, including the number of enrolled patients, age, sex, terminology for diagnosis, treatment methods, and complications were investigated for comparison in our study.

\section{RESULTS}

\section{Clinical and angiographic features}

The demographic characteristics of the 22 patients are presented in Table 1 . The mean age of all patients in the study was 21 years (range, $0-78$ years). The majority of patients were children or young adults. There were 13 male patients (59.1\%). Symptomatic lesions were noted in 14 patients : intracranial hemorrhage (ICH) in 1, seizure in 4, and headache in 7. Skin lesions caused by associated anomalies, such as SP, were seen in two patients.

The average number of CVs was $1.8 \pm 1.2$ per patient. The diameter of the CVs ranged from $5 \mathrm{~mm}$ to $16 \mathrm{~mm}$, and the

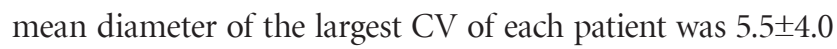
$\mathrm{mm}$. Among the $39 \mathrm{CVs}, 11(28 \%)$ were located in the deep 
Table 1. Summary of the patients in the study

\begin{tabular}{|c|c|c|c|c|c|c|c|c|c|c|}
\hline Case & $\begin{array}{l}\text { Age/ } \\
\text { sex } \\
\text { (years) }\end{array}$ & Presentation & $\begin{array}{l}\text { Treatment } \\
\text { \& result }\end{array}$ & Type & Location & $\begin{array}{c}\text { Location } \\
\text { group }\end{array}$ & Number & $\begin{array}{l}\text { Associated } \\
\text { condition }\end{array}$ & $\begin{array}{l}\text { Max. } \\
\text { diameter } \\
(\mathrm{mm})\end{array}$ & 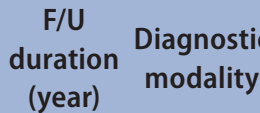 \\
\hline
\end{tabular}

Patients associated with sinus incompetency from the vein of Galen and the Straight Sinus anomaly

\begin{tabular}{|c|c|c|c|c|c|c|c|c|c|c|c|}
\hline 1 & 26/M & $\begin{array}{l}\text { Forehead skin } \\
\text { discoloration }\end{array}$ & $\begin{array}{l}\text { Observation } \\
\text { Removal of } \\
\text { SP }\end{array}$ & Fistulous & Cortical & $S$ & 3 & $\begin{array}{l}\text { Giant DVA, } \\
\text { Frontal SP, } \\
\text { AVofG }\end{array}$ & 5 & 0.2 & $\begin{array}{c}\text { MRI, MRA, } \\
\text { TFCA }\end{array}$ \\
\hline 2 & $2 / \mathrm{M}$ & Scalp lesion & $\begin{array}{l}\text { Observation } \\
\text { removal of } \\
\text { SP }\end{array}$ & Fistulous & SMCV & S & 1 & SP, AVofG & 5 & 6 & MRI, TFCA \\
\hline 3 & $8 / F$ & Headache & Observation & Fistulous & $\begin{array}{c}\text { Medullary, } \\
\text { ependymal and } \\
\text { interhemispheric } \\
\text { vein }\end{array}$ & D & 1 & $\begin{array}{c}\text { SP, VofG and } \\
\text { straight sinus } \\
\text { stenosis and } \\
\text { DVA }\end{array}$ & 5 & 0.2 & $\begin{array}{c}\text { MRI, MRA, } \\
\text { TFCA }\end{array}$ \\
\hline 4 & $15 / F$ & Headache & Observation & Fistulous & $\begin{array}{c}\text { Ventral } \\
\text { diencephalic } \\
\text { vein }\end{array}$ & D & 1 & AVofG, DVA & 7 & 15 & MRI, TFCA \\
\hline 5 & 30/M & $\begin{array}{l}\text { ICH (left PO } \\
\text { area) }\end{array}$ & Observation & Saccular & Cortical Labbe & $S$ & 2 & $\begin{array}{c}\text { Persistent } \\
\text { falcine sinus, } \\
\text { AVofG, } \\
\text { hemorrhage }\end{array}$ & 6 & 0.5 & MRI, MRV \\
\hline 6 & $16 / \mathrm{M}$ & $\begin{array}{c}\text { Headache, } \\
\text { dysarthria } \\
\text { and SAH } \\
\text { (complication } \\
\text { for } \\
\text { anticoagulation } \\
\text { therapy } \\
\text { for sinus } \\
\text { thrombosis) }\end{array}$ & Observation & Mixed & DMCV, SMCV & S & 3 & $\begin{array}{c}\text { Sinus } \\
\text { thrombosis } \\
\text { of VofG and } \\
\text { both sigmoid } \\
\text { and transverse } \\
\text { sinuses }\end{array}$ & 9 & 12 & MRI, TFCA \\
\hline 7 & $34 / \mathrm{M}$ & Headache & Observation & Mixed & $\begin{array}{c}\text { Multiple cortical } \\
\text { and ICV }\end{array}$ & S & 5 & $\begin{array}{l}\text { AVofG, GAG in } \\
\text { SSS, Absence of } \\
\text { ipsilateral SMCV }\end{array}$ & 16 & 0.3 & $\mathrm{MRI}$, TFCA \\
\hline 8 & O/M & Frontal SP & Observation & Fsitulous & Multiple cortical & $S$ & 4 & $\begin{array}{l}\text { SP, AVofG, GAG } \\
\text { and thrombuss }\end{array}$ & 10 & 2 & MRI, MRV \\
\hline
\end{tabular}

Patients associated with a large developmental venous anomaly

\begin{tabular}{|c|c|c|c|c|c|c|c|c|c|c|c|}
\hline 9 & $11 / \mathrm{M}$ & $\begin{array}{l}\text { Headache } \\
\text { seizure }\end{array}$ & Observation & Fistulous & SMCV & S & 1 & DVA & 6 & 5 & MRI, TFCA \\
\hline 10 & $25 / M$ & $\begin{array}{l}\text { Incidental } \\
\text { (check-up } \\
\text { following car } \\
\text { accident }\end{array}$ & Observation & Fistulous & Cortical & D & 1 & DVA & 6 & 7 & MRI, TFCA \\
\hline 11 & $27 / F$ & $\begin{array}{l}\text { Incidental } \\
\text { (work-up for } \\
\text { amenorrhea) }\end{array}$ & Observation & Saccular & $\begin{array}{c}\text { Pericallosal } \\
\text { vein, dorsal } \\
\text { diencephalic vein } \\
\text { and medullary } \\
\text { vein }\end{array}$ & D & 2 & DVA & 20 & 0.1 & $\begin{array}{c}\text { MRI, MRV, } \\
\text { TFCA }\end{array}$ \\
\hline 12 & $26 / F$ & Headache & Observation & Fistulous & $\begin{array}{c}\text { Ventral } \\
\text { diencephalic } \\
\text { vein, multiple } \\
\text { cortical veins }\end{array}$ & D & 1 & DVA & 7 & 11 & MRI, TFCA \\
\hline
\end{tabular}


Table 1. Continned

\begin{tabular}{|c|c|c|c|c|c|c|c|c|c|c|c|}
\hline Case & $\begin{array}{c}\text { Age/ } \\
\text { sex } \\
\text { (years) }\end{array}$ & Presentation & $\begin{array}{l}\text { Treatment } \\
\text { \& result }\end{array}$ & Type & Location & $\begin{array}{l}\text { Location } \\
\text { group }\end{array}$ & Number & $\begin{array}{l}\text { Associated } \\
\text { condition }\end{array}$ & $\begin{array}{c}\text { Max. } \\
\text { diameter } \\
(\mathrm{mm})\end{array}$ & $\begin{array}{c}\text { F/U } \\
\text { duration } \\
\text { (year) }\end{array}$ & $\begin{array}{c}\text { Diagnostic } \\
\text { modality }\end{array}$ \\
\hline 13 & $36 / M$ & $\begin{array}{c}\text { Incidental } \\
\text { (health check- }\end{array}$ & Observation & Mixed & Cortical & D & 2 & DVA & 8 & 0.2 & MRI, TFCA \\
\hline
\end{tabular}

up)

Patients associated with migration anomaly or neurocutaneous syndrome
$\begin{array}{ccccccccc}\text { Mental } & \text { Observation Fistulous } & \text { BVR } & \text { D } & 1 & \begin{array}{c}\text { Migration } \\ \text { anomaly }\end{array} & 6 & 3 \\ \begin{array}{c}\text { retardation } \\ \text { epilepsy }\end{array}\end{array}$

Patients associated with Sturge-Weber syndrome

$\begin{array}{llllllllllll}15 & 4 / F & \text { Seizure } & \text { Observation Fistulous } & \text { Right SMCV, BVR } & S & 2 & \begin{array}{c}\text { Sturge-Weber } \\ \text { syndrome }\end{array} & 10 & 0.2 & \text { MRI, TFCA } \\ 16 & 2 / F & \text { Seizure } & \text { Observation Fistulous } & \text { BVR } & \text { D } & 1 & \begin{array}{c}\text { Sturge-Weber } \\ \text { syndrome }\end{array} & 6 & 9 & \text { MRI, MRV }\end{array}$

Patients with no associated anomalies

\begin{tabular}{|c|c|c|c|c|c|c|c|c|c|c|c|}
\hline 17 & $57 / M$ & $\begin{array}{c}\text { Incidental } \\
\text { (dizziness w/u) }\end{array}$ & Observation & Fistulous & Cortical & $S$ & 1 & $\begin{array}{l}\text { Cerebromalacia, } \\
\text { focal infarction }\end{array}$ & 5 & 11 & MRI, TFCA \\
\hline 18 & $25 / F$ & $\begin{array}{l}\text { Incidental } \\
\text { (wor-up } \\
\text { for viral } \\
\text { meningitis) }\end{array}$ & Observation & Fistulous & BVR & D & 1 & None & 7 & 3 & MRI, TFCA \\
\hline 19 & $6 / M$ & $\begin{array}{l}\text { Headache, } \\
\text { dizziness }\end{array}$ & Observation & Fistulous & Cortical & S & 1 & None & 10 & 3 & $\begin{array}{c}\text { MRI, MRV, } \\
\text { TFCA }\end{array}$ \\
\hline 20 & $1 / F$ & $\begin{array}{l}\text { Incidental } \\
\text { (Jaundice) }\end{array}$ & Observation & Fistulous & Trolard & S & 1 & None & 10 & 4 & MRI, TFCA \\
\hline 21 & $15 / F$ & $\begin{array}{c}\text { Incidental } \\
\text { (Auditory } \\
\text { hallucination) }\end{array}$ & Observation & Fistulous & Cortical & S & 3 & None & 7 & 2 & MRI, MRV \\
\hline 22 & $78 / \mathrm{M}$ & $\begin{array}{l}\text { Incidental } \\
\text { (syncope) }\end{array}$ & Observation & Fistulous & Cortical & S & 1 & None & 6 & 0.1 & MRI \\
\hline
\end{tabular}

F/U : follow-up, M : male, SP : sinus pericranii, $S$ : superficial vein group, DVA : developmental venous anomalie, AVofG : agenesis or stenosis of the vein of Galen, MRI : magnetic resonance imaging, MRA : magnetic resonance angiography, TFCA : transfemoral cerebral angiography, SMCV : superficial middle cerebral vein, $\mathrm{F}$ : female, $\mathrm{D}$ : deep vein group, $\mathrm{ICH}$ : intracranial hemorrhage, $\mathrm{PO}$ : parieto-occipital, MRV : magnetic resonance venography, SAH : subarachnoid hemorrhage, DMCV : deep middle cerebral vein, ICV : internal cerebral vein, GAG : giant arachnoid granulation, SSS : superior sagittal sinus, BVR: basal vein of Rosenthal, w/u : work up

venous system, whereas $28 \mathrm{CVs}(72 \%)$ were seen in the superficial venous system.

CVs were classified as fusiform or saccular depending on their shapes as mentioned above. The majority of patients $(\mathrm{n}=17)$ had fusiform CVs (77\%), but two had saccular types (9\%) and three had both fusiform and saccular types (14\%).

Also, patients were classified according to relevant anomalies, which are organized in Table 1 together with the demographics and clinical information for each patient. Eight patients exhibited a compromised vein of Galen and straight sinus. Among them, four patients had SPs. The frequency of SP was significantly higher in those eight patients with com- promised anatomy than in other patients ( $p$ value $=0.005$ using Fisher's exact test). Other associated anomalies included DVAs (not directly draining into CVs), giant arachnoid granulations, and embryonic veins (e.g., ventral diencephalic vein and persistent falcine sinus).

Five patients had large DVAs draining into the CVs. Two of them presented with headache, and the rest were incidentally discovered. There were three patients with an associated migration anomaly, neurocutaneous syndrome or Sturge-Weber syndrome. All of these patients presented with seizure. Presentation with seizures in these patients was statistically significant compared to the incidence of seizures in other pa- 
tients ( $p$ value $=0.001$ using Fisher's exact test).

Six patients had no identifiable associated anomalies, and most of them were asymptomatic.

\section{Long-term clinical outcomes}

Of the $39 \mathrm{CVs}$ in 22 patients, 20 lesions in 14 patients were followed up for 2 years or longer. Among them, no adverse events were reported. Their mean follow-up period was 6.6 years (range, 2-15 years). A total of 14 symptomatic patients, including one patient with ICH, were managed conservatively.

\section{Review of the patient literature}

In literature, fifteen cases of nonfistulous CVs were reported between 1978 and 2017 (Table 2). Two patients (13\%) had hemorrhage, and another two (13\%) had thrombosis at presentation $^{11,12,23,33)}$. Headache was reported in four patients $(26 \%)^{6,8,30,31)}$. Seven cases (47\%) were discovered incidentally. Overall, seven patients underwent surgery (47\%) : one died on

Table 2. Literature review of cases in nonfistulous CVs and their clinical features

\begin{tabular}{|c|c|c|c|c|c|c|c|c|c|c|c|}
\hline $\begin{array}{l}\text { Case } \\
\text { No. }\end{array}$ & Author & Year & $\begin{array}{c}\text { Age/ } \\
\text { sex } \\
\text { (years) }\end{array}$ & Presentation & $\begin{array}{l}\text { Treatment and } \\
\text { result }\end{array}$ & Location & $\begin{array}{l}\text { Location } \\
\text { group }\end{array}$ & Number & $\begin{array}{l}\text { Associated } \\
\text { condition }\end{array}$ & $\begin{array}{l}\text { Size } \\
(/ \mathrm{mm})\end{array}$ & $\begin{array}{c}\text { Diagnostic } \\
\text { modality }\end{array}$ \\
\hline 1 & $\begin{array}{c}\text { Tyson et } \\
\text { al. }^{33)}\end{array}$ & 1978 & $83 / F$ & Hemorrhage & Surgery, death & SMCV & $S$ & 1 & None & 5 & $\begin{array}{c}\text { TFCA, } \\
\text { autopsy }\end{array}$ \\
\hline 2 & $\begin{array}{l}\text { Tanohata } \\
\text { et al. }^{32)}\end{array}$ & 1986 & $50 / F$ & Incidental & Observation & Cortical & S & 1 & None & $12 \times 5$ & $C T, T F C A$ \\
\hline 3 & $\begin{array}{l}\text { Roda et } \\
\text { al. }^{23)}\end{array}$ & 1988 & $51 / F$ & $\begin{array}{l}\text { Intraventricular } \\
\text { hemorrhage }\end{array}$ & Surgery & $\begin{array}{l}\text { Thalamostriate vein- } \\
\text { ICV junction }\end{array}$ & D & 1 & None & 6.5 & $\mathrm{CT}, \mathrm{TFCA}$ \\
\hline 4 & $\begin{array}{l}\text { Nishioka } \\
\text { et al. }{ }^{17)}\end{array}$ & 1990 & $69 / M$ & Seizure & Observation & DMCV & D & 1 & None & 7 & MRI, TFCA \\
\hline 5 & $\begin{array}{c}\text { Shibata et } \\
\text { al. }^{28)}\end{array}$ & 1991 & $11 / \mathrm{M}$ & Incidental & Observation & DMCV & $\mathrm{D}$ & 1 & None & 10 & $\begin{array}{l}\text { CT, MRI, } \\
\text { TFCA }\end{array}$ \\
\hline 6 & $\begin{array}{l}\text { Kelly et } \\
\text { al. }\end{array}$ & 1995 & $17 / F$ & Thrombosis & Surgery & DMCV & D & 1 & None & $20 \times 20$ & $\mathrm{CT}, \mathrm{MRI}$ \\
\hline 7 & $\begin{array}{l}\text { Kazumata } \\
\text { et al. }\end{array}$ & 1999 & $24 / F$ & Incidental & $\begin{array}{l}\text { Surgery for IJV } \\
\text { Aneurysm }\end{array}$ & Multiple cortical & S & 10 & $\begin{array}{l}\text { Anterior } \\
\text { and } \\
\text { middle SSS } \\
\text { hypoplasia, } \\
\text { IJV } \\
\text { Aneurysm }\end{array}$ & $8 \times 7 \times 7$ & $\begin{array}{l}\text { CT, MRI, } \\
\text { TFCA }\end{array}$ \\
\hline 8 & $\begin{array}{l}\text { Saigal et } \\
\text { al. }^{24)}\end{array}$ & 2003 & $65 / M$ & Incidental & Observation & SMCV & S & 1 & None & - & $C T, M R I$ \\
\hline 9 & $\begin{array}{l}\text { Kondo et. } \\
\text { al. }^{12)}\end{array}$ & 2004 & $39 / F$ & $\begin{array}{c}\text { Seizure } \\
\text { Thrombosis }\end{array}$ & $\begin{array}{l}\text { Shrunken, after } \\
\text { thrombosis }\end{array}$ & Trolard & S & 1 & None & - & $\begin{array}{l}\text { CT, MRI, } \\
\text { TFCA }\end{array}$ \\
\hline 10 & $\begin{array}{c}\text { Hoell et } \\
\text { al. }^{8)}\end{array}$ & 2004 & $40 / F$ & Headache & Surgery & $\begin{array}{l}\text { Cortical vein } \\
\text { Rt. F }\end{array}$ & S & 1 & None & & MRI \\
\hline 11 & $\begin{array}{l}\text { Tanju et } \\
\text { al. }^{311}\end{array}$ & 2006 & $35 / F$ & Headache & Observation & Trolard & $S$ & 1 & None & - & MRV \\
\hline 12 & $\begin{array}{l}\text { Inoue et } \\
\text { al. }^{9)}\end{array}$ & 2014 & $55 / F$ & $\begin{array}{l}\text { Trigeminal } \\
\text { neuralgia }\end{array}$ & Surgery (MVD) & $\begin{array}{c}\text { Basal vein of } \\
\text { Rosenthal }\end{array}$ & D & 1 & & & $C T, M R I$ \\
\hline 13 & $\begin{array}{c}\text { Gomez et } \\
\text { al. }^{6)}\end{array}$ & 2016 & $12 / F$ & Headache & Observation & $\begin{array}{l}\text { Superficial sylvian } \\
\text { vein }\end{array}$ & S & 1 & & & MRI, CTA \\
\hline 14 & $\begin{array}{l}\text { Tan et } \\
\text { al. }^{30)}\end{array}$ & 2016 & $59 / F$ & Headache & $\begin{array}{l}\text { Surgical } \\
\text { resection } \\
\text { (misdiagnosis) }\end{array}$ & Cortical (Rt. frontal) & S & 1 & & $11 \times 11$ & MRI \\
\hline 15 & $\begin{array}{l}\text { Ozturk et } \\
\text { al. }^{20)}\end{array}$ & 2017 & $1 / \mathrm{M}$ & Incidental & Observation & Cortical (Rt. parietal) & S & 1 & & 20 & $\begin{array}{l}\text { MRI, CT, } \\
\text { TFCA }\end{array}$ \\
\hline
\end{tabular}

CV : cerebral varice, F : female, SMCV : superficial middle cerebral vein, $\mathrm{S}:$ superficial vein group, TFCA : transfemoral catheter angiography, CT : computed tomography, ICV : internal cerebral vein, D : deep vein group, M : male, DMCV : deep middle cerebral vein, MRI : magnetic resonance imaging, IJV : internal jugular vein, SSS : superior sagittal sinus, Rt. F : right frontal, MRV : magnetic resonance venography, MVD : microvascular decompression 
the third postoperative day, but the cause of death was not stated $^{33)}$. Another patient developed hemiplegia postoperatively, but the symptoms progressively improved ${ }^{23)}$. The rest of the patients recovered uneventfully. Among those who were managed conservatively, no morbidity or mortality had been reported.

\section{Illustrative cases}

\section{Case 6}

A 16-year-old boy presented with a two-week history of intermittent headache. He underwent investigation including brain computed tomography (CT), magnetic resonance imaging (MRI), and TFCA, which showed thrombosed superior sagittal sinus and bilateral transverse and sigmoid sinuses (Fig. 1). There was no evidence of dural arteriovenous fistula (AVF). He was started on anticoagulation therapy. After a week, his headache worsened and the follow-up brain CT showed an acute subarachnoid hemorrhage. Anticoagulation was stopped and the patient was managed conservatively. Follow-up TFCA showed persistent occlusion of sinuses and CVs on superficial venous system. Later, he was diagnosed with inflammatory

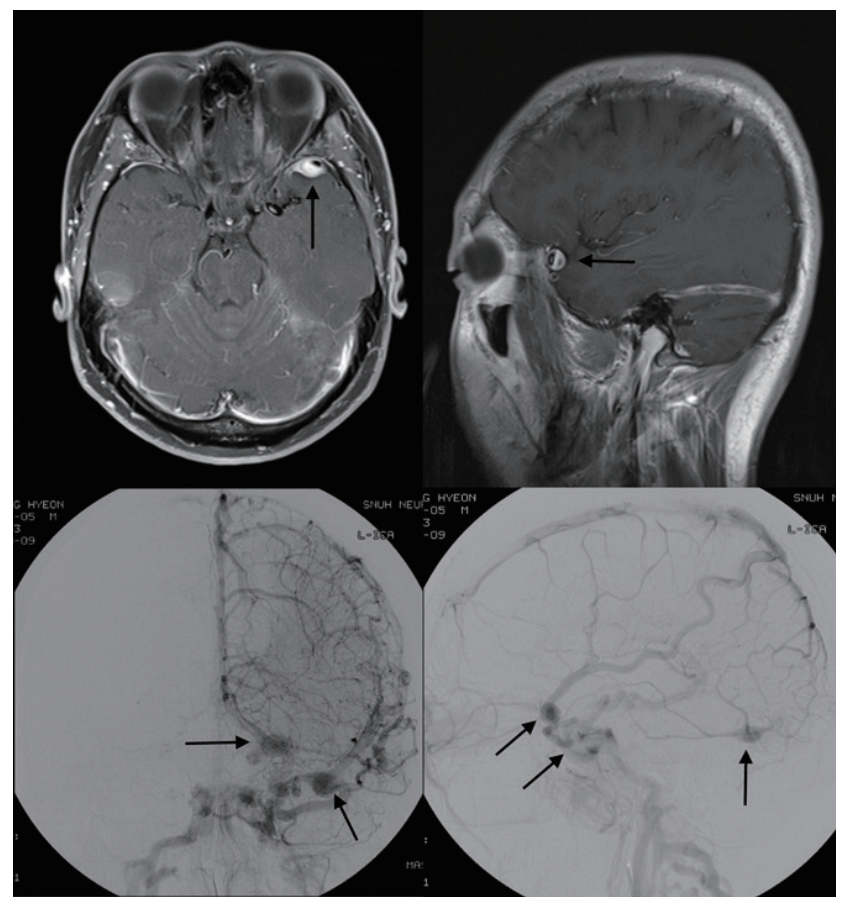

Fig. 1. Magnetic resonance imaging and left internal carotid artery angiography of patient 6 showed thrombosed posterior SSS and bilateral transverse sigmoid sinuses. Black arrows show CVs; two are saccular and one is fusiform. SSS : superior sagittal sinus. myofibroblastic tumor on the right parotid gland and it was thought to be the cause of the thrombosis. He was restarted on anticoagulation therapy for thrombosis but was managed conservatively regarding the CVs. Follow-up brain MRI scans showed no significant change in those malformations, and the patient remains symptom free, although he continued to have intermittent headaches.

\section{Case 20}

An 11-month-old girl presented with an abnormal brain sonography result. She was previously healthy except a history of

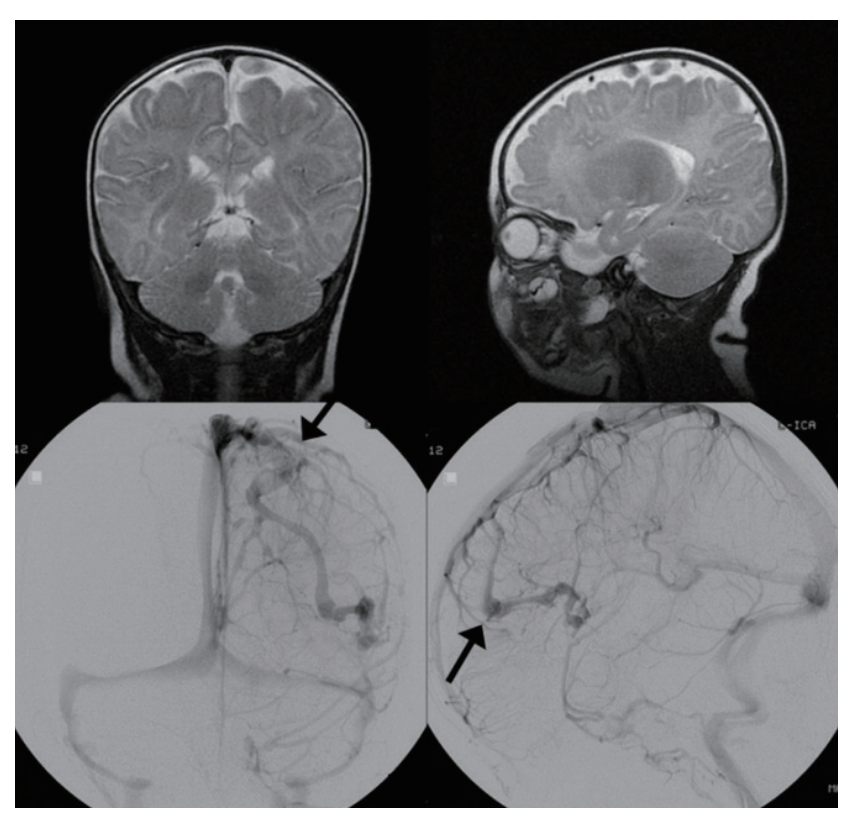

Fig. 2. Non-contrast magnetic resonance imaging, coronal and sagittal views, and left internal carotid artery angiography of patient 20. An isolated cerebral varix of fusiform type (black arrows) was identified.

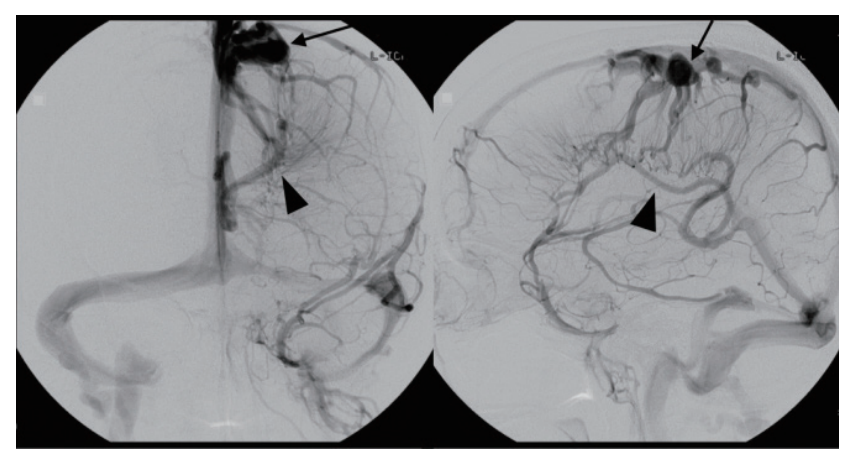

Fig. 3. Left internal carotid artery angiography of patient 11 whose CV was discovered incidentally. A large developmental venous anomalie was noted, draining medullary veins (black arrowheadeds) and a large saccular type CV was seen (black arrows). CV : cerebral varix. 
jaundice. The brain MRI showed cerebral cortical venous engorgement in the left sylvian area, and it appeared to drain to the posterior portion of the superior sagittal sinus, suggesting a diagnosis of dural AVF. However, left internal carotid artery angiography showed a venous engorgement of the left superficial vein without evidence of fistula (Fig. 2). The patient remained symptom free and had an unremarkable development.

\section{Case 11}

A 27 year old female was referred to our clinic with an abnormal finding on MRI. She had amenorrhea secondary to prolactinoma in the sellar area. Otherwise, she was symptom free. TFCA was performed and showed a large DVA and a CV on the superficial venous system (Fig. 3). Unfortunately, she was lost in the follow-up.

\section{DISCUSSION}

\section{Clinical outcomes}

From the literature review, it appeared that a large proportion of nonfistulous CVs were clinically silent and found incidentally. In our study, 63.6\% (14 of 22 patients) of patients were symptomatic, and headache was the most common presenting symptom. However, it was difficult to show a direct correlation between the lesions and headache. This was the same for seizure, which was the second most common presenting symptom. The location of lesions did not match the seizure activity according to the electroecephalography (EEG) in most cases. Accordingly, it might be more appropriate to consider that most patients had nonspecific symptoms, such as headache or seizure, and that the CVs were found by accident. For example, three out of four patients who presented with seizure and their epilepsy was considered to be related to congenital anomalies rather than CVs. In only one case the association between the CV and seizure could not be ruled out due to the lack of mandatory information, such as EEG data or a description of semiology.

In literature, $26 \%$ of patients presented with either hemorrhage or thrombosis of CVs. This is much higher than the prevalence seen in our study (4.5\%). This discrepancy may be due to the small numbers of patients in studies. Also, it should be noted that atypical presentation, e.g., symptomatic patients, is more likely to be reported in literature than a typical case, overestimating the true incidence of symptoms.

In previous studies, $47 \%$ of patients underwent surgery. However, surgeries were intended for symptom relief, not for prevention of symptom. The benefits of surgery were not established and, therefore, the surgery should be reserved for symptomatic patients.

CVs often operate as an alternative drainage channel for congenital anomalies, such as agenesis of vein of Galen. As a result, rare manifestation of symptoms from hemorrhage or thrombosis has been reported, and regular follow-up visits are recommended.

To our knowledge, this is the largest study to evaluate the clinical outcomes of nonfistulous CVs. However, the followup duration of our study was limited to an average of 6.9 years, and the follow-up time was not always clear in the literature. Long-term prospective observational study is required to verify the benign nature of CVs.

\section{Pathogenesis of CVs}

Patients identified by the abovementioned criteria were heterogeneous. Clinically, patients with sinus compromise were the most remarkable. All patients in this group showed compromise of the vein of Galen and straight sinus (Table 1, Fig. 1). CVs were not directly proximal to the atretic vein of Galen or straight sinus. Instead, they were dilated cortical veins that drained into other sinuses or the pterygopalatine plexus. They were alternative drainage channels to the compromised vein of Galen. Sinus thrombosis seemed to aggravate sinus compromise. Due to the sinus compromise, patients possibly had significant venous hypertension.

In a previous report from our group, venous hypertension from sinus compromise was suggested as a developmental cause of SPs ${ }^{21)}$. The significantly increased frequency of SPs in these patients supports that they would have venous hypertension from sinus compromise. Lasjaunias et al. ${ }^{13)}$ also suggested that venous obstruction causes nonfistulous CVs. According to them, the superficial and deep venous systems are in equilibrium, and an obstruction in the venous system leads to an increased pressure upstream, resulting in a CV. Our results support this assertion.

Some CVs were distal draining veins of DVAs (Table 1). DVAs are the most common type of vascular malformations, with an incidence of up to $2.6 \%{ }^{12)}$. It is now widely ac- 
cepted that they are congenital and result as a compensatory venous system for abnormal development of veins in the central nervous system ${ }^{1)}$. The coexistence of CV and DVA is uncommon. In English literature, there have been only 15 cases where CV and DVA were observed in the same patie

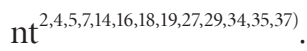

Four patients (18\%) had congenital malformations, either a migration anomaly or Sturge-Weber syndrome. Those anomalies were associated with various parenchymal abnormalities, which were thought to result in venous hypertension and $\mathrm{CVs}^{26}$. Additionally, venous and microvascular occlusion are well-known and prominent features of Sturge-Weber syndrome $e^{3,25)}$.

Based on these findings, we carefully suggested that nonfistulous CVs may be congenital in origin. Various characteristics support this hypothesis. One is an association with congenital abnormalities including agenesis of the vein of Galen, sinus stenosis, SP, DVA, migration anomalies, and Sturge-Weber syndrome (Table 1). In addition, persistence and enlargement of an alternative embryologic venous drainage channel, including the ventral diencephalic vein and falcine sinus, in our series support the developmental origin.

Eight CVs had no associated anomalies and the median age of these patients was highest compared to the others. Causes of these isolated CVs are still obscure. One of the hypotheses by Gomez et al. ${ }^{6}$ is that transient venous obstructions during the developmental period create isolated CVs. However, they might not be congenital in origin and this should be further investigated.

\section{CONCLUSION}

In general, nonfistulous CVs do not cause symptoms, and we suggest they should be managed conservatively. However, rare manifestation of symptoms due to hemorrhage or thrombosis has been reported, and regular follow-up visits are recommended.

Although the clinical features of nonfistulous CVs are heterogeneous, most of them were closely related to congenital anomalies. Venous obstructions, such as compromise of the vein of Galen or straight sinus during development seemed to play a role in pathogenesis.

\section{CONFLICTS OF INTEREST}

No potential conflict of interest relevant to this article was reported.

\section{INFORMED CONSENT}

This type of study does not require informed consent.

\section{- Acknowledgements}

This study was supported by a grant $(0620163110,2016$ 2247) from Seoul National University Hospital.

\section{References}

1. Aydin I, Kadioğlu H, Tüzün Y, Kayaoğlu C, Takci E : The variations of Sylvian veins and cisterns in anterior circulation aneurysms. An operative study. Acta Neurochir 138 : 1380-1385, 1996

2. Boukobza M, Enjolras O, Guichard JP, Gelbert F, Herbreteau D, Reizine D, et al. : Cerebral developmental venous anomalies associated with head and neck venous malformations. AJNR Am J Neuroradiol 17 : 987994, 1996

3. Curé JK, Holden KR, Van Tassel P: Progressive venous occlusion in a neonate with Sturge-Weber syndrome: demonstration with MR venography. AJNR Am J Neuroradiol 16 : 1539-1542, 1995

4. Damiano TR, Truwit CL, Dowd CF, Symonds DL, Portela L, Dreisbach J : Posterior fossa venous angiomas with drainage through the brain stem. AJNR Am J Neuroradiol 15 : 643-652, 1994

5. Dross P, Raji MR, Dastur KJ : Cerebral varix associated with a venous angioma. AJNR Am J Neuroradil 8 : 373-374, 1987

6. Gomez DF, Mejia JA, Murcia DJ, Useche N : Isolated giant cerebral varix - a diagnostic and therapeutic challenge: a case report. Surg Neurol Int 7(Suppl 5) : S156-S159, 2016

7. Handa J, Suda K, Sato M : Cerebral venous angioma associated with varix. Surg Neurol $21:$ 436-440, 1984

8. Hoell T, Hohaus C, Beier A, Holzhausen HJ, Meisel HJ : Cortical venous aneurysm isolated cerebral varix. Interv Neuroradiol 10 : 161-165, 2004

9. Inoue T, Shima A, Hirai H, Suzuki F, Matsuda M : Trigeminal neuralgia due to an isolated cerebral varix: case report. J Neurol Surg Rep 75 : e206-209, 2014

10. Kazumata K, Fujimoto S, Idosaka H, Kuroda S, Nunomura M, Houkin K : Multiple varices in the unilateral cerebral venous system. AJNR Am J Neuroradiol 20 : 1243-1244, 1999

11. Kelly KJ, Rockwell BH, Raji MR, Altschuler EM, Martinez AJ : Isolated cerebral intraaxial varix. AJNR Am J Neuroradiol 16 : 1633-1635, 1995 
12. Kondo T, Mori Y, Kida Y, Kobayashi T, Iwakoshi T : Isolated cerebral varix developing sudden deterioration of neurological status because of thrombosis: a case report. Surg Neurol 62 : 76-78; discussion 78-79, 2004

13. Lasjaunias $P$, Burrows $P$, Planet $C$ : Developmental venous anomalies (DVA): the so-called venous angioma. Neurosurg Rev 9 : 233-242, 1986

14. Maiuri F, Gangemi M, laconetta $G$ : Giant intracranial varix associated with venous angioma and intracerebral hemorrhage. Acta neurol (Napoli) 12 : 231-236, 1990

15. McCormick WF : The pathology of vascular ("arteriovenous") malformations. J Neurosurg $24: 807-816,1966$

16. Meyer JD, Baghai P, Latchaw RE : Cerebral varix and probable venous angioma: an unusual isolated anomaly. AJNR Am J Neuroradiol 4 : 85-87, 1983

17. Nishioka T, Kondo A, Nin K, Tashiro H, Ikai Y, Takahashi J : Solitary cerebral varix. Case report. Neurol Med Chir (Tokyo) 30(11 spect No) : 904-907, 1990

18. Numaguchi Y, Nadell JM, Mizushima A, Wilensky MA : Cerebral venous angioma and a varix: a rare combination. Comput Radiol $10: 319$ 323, 1986

19. Ostertun B, Solymosi L : Magnetic resonance angiography of cerebral developmental venous anomalies: its role in differential diagnosis. Neuroradiology 35 : 97-104, 1993

20. Ozturk M, Aslan S, Ceyhan Bilgici M, Idil Soylu A, Aydin K : Spontaneous thrombosis of a giant cerebral varix in a pediatric patient. Childs Nerv Syst 33 : 2193-2195, 2017

21. Park SC, Kim SK, Cho BK, Kim HJ, Kim JE, Phi JH, et al. : Sinus pericranii in children: report of 16 patients and preoperative evaluation of surgical risk. J Neurosurg Pediatr 4 : 536-542, 2009

22. Pritz MB : Ruptured supratentorial arteriovenous malformations associated with venous aneurysms. Acta Neurochir (Wien) 128 : 150-162, 1994

23. Roda JM, Bencosme J, Isla A, Blázquez MG : Intraventricular varix causing hemorrhage. Case report. J Neurosurg $68:$ 472-473, 1988

24. Saigal $G$, Villalobos $E$ : A variant of the superficial middle cerebral vein mimicking an extraaxial hematoma. AJNR Am J Neuroradiol 24 : 968-970, 2003
25. Sarwar M : Deep venous occlusion in the Sturge-Weber syndrome. Rev Interam Radiol 2 : 159-161, 1977

26. Sarwar M, McCormick WF : Intracerebral venous angioma, Case report and review. Arch Neurol 35 : 323-325, 1978

27. Sherry RG, Walker ML, Olds MV : Sinus pericranii and venous angioma in the blue-rubber bleb nevus syndrome. AJNR Am J Neuroradil 5 : 832-834, 1984

28. Shibata Y, Hyodo A, Tsuboi $K$, Yoshii $Y$, Nose T : Isolated cerebral varix with magnetic resonance imaging findings--case report. Neurol Med Chir (Tokyo) 31 : 156-158, 1991

29. Sirin S, Kahraman S, Gocmen S, Erdogan E : A rare combination of a developmental venous anomaly with a varix. Case report. J Neurosurg Pediatr 1 : 156-159, 2008

30. Tan ZG, Zhou Q, Cui Y, Yi L, Ouyang Y, Jiang Y : Extra-axial isolated cerebral varix misdiagnosed as convexity meningioma: a case report and review of literatures. Medicine (Baltimore) 95 : e4047, 2016

31. Tanju S, Ustuner E, Deda H, Erden I : Cerebral varix simulating a meningioma: use of 3D magnetic resonance venography for diagnosis. Curr Probl Diagn Radiol 35 : 258-260, 2006

32. Tanohata K, Machara T, Noda M, Katoh H : Isolated cerebral varix of superficial cortical vein: CT demonstration. J Comput Assit Tomogr 10 : 1073-1074, 1986

33. Tyson GW, Jane JA, Strachan WE : Intracerebral hemorrhage due to ruptured venous aneurysm. Report of two cases. J Neurosurg 49 : 739 743, 1978

34. Uchino A, Hasuo K, Matsumoto S, Ikezaki K, Masuda K: Varix occurring with cerebral venous angioma: a case report and review of the literature. Neuroradiology 37 : 29-31, 1995

35. Vattoth S, Purkayastha S, Jayadevan ER, Gupta AK : Bilateral cerebral venous angioma associated with varices: a case report and review of the literature. AJNR Am J Neuroradiol 26 : 2320-2322, 2005

36. ViñUela F, Drake CG, Fox AJ, Pelz DM : Giant intracranial varices secondary to high-flow arteriovenous fistulae. J Neurosurg 66 : 198-203, 1987

37. Wilms G, Demaerel P, Robberecht W, Plets C, Goffin J, Carton H, et al. : Coincidence of developmental venous anomalies and other brain lesions: a clinical study. Eur Radiol 5 : 495-500, 1995 